\title{
FAMILIAL HYPOGLYCEMIA PRECIPITATED BY AMINO ACIDS
}

\author{
By W. A. COCHRANE, 1 W. W. PAYNE, M. J. SIMPKISS, ANd L. I. WOOLF \\ (From the Hospital for Sick Children, Great Ormond Street, London, W. C. 1, England)
}

(Submitted for publication September 13, 1955; accepted November 23, 1955)

Mann and Magath (1) in 1922 first described the clinical symptoms associated with hypoglycemia, and in 1924 Harris (2) reviewed its relationship to hyperinsulinism. Since then, numerous articles have appeared in the literature reviewing the causes of hypoglycemia, (3-6) describing individual cases and suggesting various surgical and medical methods of management.

Although spontaneous hypoglycemia is evidence of abnormal carbohydrate metabolism, this abnormality may be due to a variety of diseases.

The present communication describes three cases of hypoglycemia occurring in one family, and one unrelated case, in which convulsions and profound lowering of the blood glucose were induced by the administration of proteins or amino acids.

We believe this abnormal relationship between amino acids and glucose metabolism has not been previously described, and will be of great interest, not only to the clinician, but also to the biochemist and physiologist investigating carbohydrate and protein metabolism.

\section{CASES}

Case 1. A female infant was admitted to The Hospital for Sick Children, Great Ormond Street on 29th September 1954, at the age of 4 months for investigation of convulsions. Her mother's pregnancy and labor were normal. Her birth weight was $7 \mathrm{lbs}$. The infant was breast fed for 10 weeks and then given half cream cow's milk feeds with added sugar. At 3 months she began to have generalized convulsions. She had two or three fits every day and these usually occurred about midway between feeds but not after waking in the mornings. The fits lasted from a few minutes to half-an-hour.

Examination showed a plump $12 \mathrm{lb} .3 \mathrm{oz}$. infant with no abnormal physical signs. Her mental development was normal for her age. Since her sister (case 2) had convulsions associated with hypoglycemia, fasting blood was taken and this showed blood sugar levels varying from 40 to $60 \mathrm{mg}$. per $100 \mathrm{ml}$. The levels of blood sugar before feeds showed a gradual decline throughout the

1 Present address: The Hospital for Sick Children, 555 University Ave., Toronto, Ontario, Canada. day-the fasting level being around $50 \mathrm{mg}$. per $100 \mathrm{ml}$. and by 10 p.m. the level had dropped to around $30 \mathrm{mg}$. per $100 \mathrm{ml}$.

An electro-encephalogram, carried out when the blood sugar level was $38 \mathrm{mg}$. per $100 \mathrm{ml}$., was normal.

The plasma level of insulin-like activity was estimated by Dr. P. J. Randle $(7, c f .8,9)$ and was found to be normal.

A high protein low carbohydrate diet (cow's milk with added casein) was then given and she immediately began to have convulsions which occurred at about one hour after each feed. On "Soylac," a soya flour synthetic milk, she had numerous convulsions, her fasting blood sugar was only $20 \mathrm{mg}$. per $100 \mathrm{ml}$. and this tended to drop slightly during the day. She was then fed with expressed breast milk, the levels of blood sugar before feeds were higher and the baby was free from fits for the first time. Cow's milk diluted with three parts of water and with added sugar had the same effect. Mixed feeding was started, care being taken to see that no large amount of protein was given without carbohydrate being given at the same time. She has remained well, having about one fit every six weeks. Her mental and physical development are normal.

Case 2. A female infant, elder sister of case 1, was admitted to The Hospital for Sick Children, Great Ormond Street on 30th May 1953 at the age of 21/2 months. Her birth weight was $7 \mathrm{lb}$. $1 \mathrm{oz}$. and her mother's pregnancy and labor were normal. She was breast fed for two months and then given full cream dried cow's milk feeds. After one week she began having generalized convulsions dating from the time when extra sugar was omitted from her feeds. During the fits she became flushed, sweated, and lost consciousness. She had about twelve fits in the three weeks prior to admission. No history of their relation to feeds could be obtained. Examination showed a small infant who weighed $7 \mathrm{lb} .10$ oz. There were no abnormal signs and her mental development was within the normal range for her age. The C.S.F. was normal apart from a sugar value of 25 mg. per $100 \mathrm{ml}$. An E.E.G. was normal. The fasting blood sugar levels varied from $32 \mathrm{mg}$. per $100 \mathrm{ml}$. to $50 \mathrm{mg}$. per $100 \mathrm{ml}$. Blood sugar levels just before meals were in the range of 40 to $65 \mathrm{mg}$. per $100 \mathrm{ml}$.

A laparotomy was performed; the pancreas was normal in size but rather firm and portions of the tail of the pancreas and of the liver were removed for histological study. There was no evidence of any neoplastic or hyperplastic change in the islets and no significant pathological change in the islet cells except that there was some enlargement, vacuolation and loss of granular dis- 
tinction in the $\beta$-cells which was interpreted as due to edema, a change which was also noted in the interstitial tissue. Both $\alpha$ - and $\beta$-cells were present in normal numbers. The histology of the liver was normal and there was no evidence of glycogen storage disease.

She was sent home in October 1953 on a normal diet with only an 8-hour fast at night, as during the latter part of her stay in hospital there was a spontaneous improvement in her condition. Two months later she was admitted with intestinal obstruction due to herniation of small intestine through the mesocolon. One foot of small bowel was resected, and although her condition at the time was poor, recovery was uneventful. After recovery she was put on normal mixed feeding and had no fits. During the following year she had a fit about once every 3 months. She sat up at ten months, walked at one year and began to talk at 20 months.

She was re-admitted for further investigation on April 12 th 1955.

Case 3-is the father of cases 1 and 2 and is 27 years old. He had fits as a baby. From 10 months of age until he was 13 years old he would occasionally fall into a deep sleep which lasted from a few moments to 3 or 4 days; this was considered to be a form of narcolepsy but the hospital records could not be traced. He has remained well since then and has no sweating or sensations which could be attributed to hypoglycemia. His fasting blood sugar was estimated on three occasions and found to be 64,46 and $48.5 \mathrm{mg}$. per $100 \mathrm{ml}$., respectively (the first two values are of "apparent sugar" estimated by the method of Folin and Wu, the third is "true sugar" estimated as described below). His plasma level of insulin-like activity was normal $(7, c f .8$ and 9$)$.

Family history: Cases 1 and 2 are the only children of case 3. There were no still-births or miscarriages. Repeated attempts to trace other members of the father's family have failed. There is no history of epilepsy in the mother's family.

Case 4-was the only child of healthy Cypriot parents. One of the mother's uncles is said to have had fits but no further details could be obtained. He was admitted to The Hospital for Sick Children, Great Ormond Street on 26th March 1952 at the age of 5 months for the investigation of convulsions. His mother's pregnancy and labor were normal. His birth weight was $6 \mathrm{lb} .14$ ozs. He was breast fed until he was $31 / 2$ months old when he was given full cream dried cow's milk feeds with added sugar. When he was 2 months old he began to have fits. At first he went pale without sweating, rolled up his eyes and did not respond to external stimuli. These fits occurred 2 to 3 times daily, usually during a feed, and they lasted about two minutes. Over a period of a few weeks he began to have more frequent and generalized convulsions unrelated to feeds. He was then admitted for further investigation.

Examination showed a large hypotonic infant weighing $12 \mathrm{lb} .2 \mathrm{oz}$. He did not hold up his head neither did he attempt to grasp an object, nor follow a light. There were no other abnormal signs.

The cerebro-spinal fluid was normal apart from a sugar value of $20 \mathrm{mg}$. per $100 \mathrm{ml}$. His fasting blood sugar levels ranged from 17 to $50 \mathrm{mg}$. per $100 \mathrm{ml}$. Preprandial blood sugars remained between 35 and 45 mg. per $100 \mathrm{ml}$.

On 6th January 1953 a laparotomy was carried out. The pancreas appeared large but otherwise normal. The distal two-thirds were removed. There was about four times the normal amount of islet tissue present, this was partly grouped in well formed islets but in addition there were islet cells grouped in strands and small acini infiltrating between the acini of exocrine tissue. There was no evidence of neoplastic change and no increase in interstitial tissue. The majority of cells were $\beta$-cells and a minority were $\alpha$-cells.

A liver biopsy carried out at the same time showed no evidence of glycogen storage disease. The plasma level of insulin-like activity was six times normal before operation, twenty months after operation it was five times normal $(7$, cf. 8 and 9$)$. Following operation his fasting blood sugar fell over 3 months from 50 to $25-30$ mg. per $100 \mathrm{ml}$. He was given cortisone for 8 months and during this time had no fits. Since then he has had only one fit every four to six weeks apart from a period of 2 to 3 months when he had 2 to 3 fits a week. He is given frequent meals and phenobarbitone.

Although his development appeared to be normal until the onset of fits at two months of age, he is now three years and four months old and is grossly retarded. He began to walk with help when two years old, but is still unable to walk unaided. He does not speak, has to be fed and has no control over micturition and defecation.

\section{MATERIALS AND METHODS}

The blood sugar concentration was followed in cases $1,2,3$, and 4 and in normal subjects after feeding glucose, casein, gelatine, leucine, tyrosine, or isovaleric acid and after injecting insulin, glucagon or adrenaline.

L-leucine puriss and L-tyrosine were used as purchased from L. Light \& Co. Ltd. They were suspended in a little water or in 3 per cent methylcellulose which was flavored with saccharin and oil of orange and frozen to an "ice cream."

Isovaleric acid, laboratory reagent grade, was dissolved in a slight excess of aqueous sodium bicarbonate solution and chilled.

Casein ("Casilan," Glaxo) and gelatine were suspended in a little water.

Biodeminrolit G (Permutit, Ltd.) was saturated with carbon dioxide and kept in a tightly closed jar.

Sodium tungstate: a 10 per cent aqueous solution was used.

Sulphuric acid : $0.66 \mathrm{~N}$.

Alkaline copper reagent (10):

A : $\mathrm{CuSO}_{4} \cdot 5 \mathrm{H}_{2} \mathrm{O}: 2 \mathrm{~g}$., $\mathrm{Na}_{2} \mathrm{SO}_{4}: 18 \mathrm{~g}$., water to $100 \mathrm{ml}$.

B : $\mathrm{Na}_{2} \mathrm{CO}_{3}$ : 12 g., Rochelle salt 6 g., $\mathrm{NaHCO}_{8}: 8$ g., $\mathrm{Na}_{2} \mathrm{SO}_{4}: 72 \mathrm{~g}$., water to $400 \mathrm{ml}$.

These were mixed in the ratio of one part $A$ to four parts B immediately before use. 
Arsenomolybdic acid was prepared by the method of Nelson (11).

Blood sugar estimation. After an overnight fast (7 to 14 hours) a specimen of capillary blood was collected by finger-prick or heel-prick into a bottle containing fluoride and oxalate. The test-substance was fed, the time taken to swallow it was noted, and blood samples were taken $10,20,30,45,60$, and 90 minutes after all the substance had been ingested.

The blood sugar estimations were carried out as soon as all the blood samples had been collected. Four-tenths $\mathrm{ml}$. of each sample (or less if the blood sample was unusually small) was added from a pipette calibrated "to contain" to $6.8 \mathrm{ml}$. of water in a centrifuge tube and mixed. Four-tenths ml. of sodium tungstate and $0.4 \mathrm{ml}$. of sulphuric acid were added to each tube and the contents well shaken. After centrifuging, the supernatant from each tube was shaken with Biodeminrolit G (about $0.75 \mathrm{ml}$. in volume) for 5 minutes. The sugar in the supernatant was estimated by the alkaline copper arsenomolybdate method and compared with a standard solution of glucose treated similarly $(10,11)$. The color intensities were read against the blank in a photo-electric colorimeter using an Ilford 604 filter $\left(\lambda_{\max }=520 \mathrm{~m} \mu\right)$.

Blood amino-acid values. These were determined by the method of West, Wilson, and Eyles (12).

Paper chromatography. For investigating the blood sugars the tungstic acid filtrate, after treatment with Biodeminrolit $\mathrm{G}$, was examined by paper chromatography $(13,14)$. Urine was treated with Biodeminrolit $G$ and similarly examined.

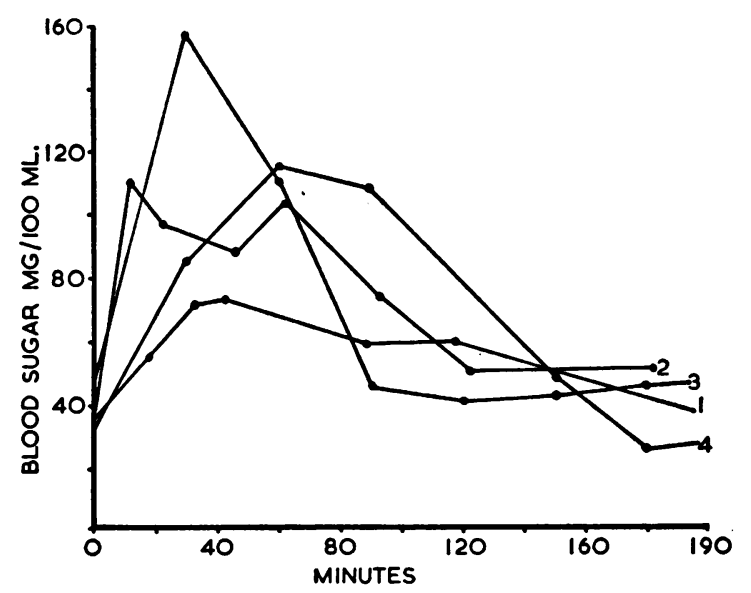

Fig. 1. Glucose Tolerance Curves

Curve 1: true blood sugar of case 1 fed $14 \mathrm{~g}$. glucose (1.6 g. per kg. body weight) over 13 mins. Curve 2: true blood sugar of case 2 fed $15.5 \mathrm{~g}$. glucose $(1.45 \mathrm{~g}$. per kg.) over 2 mins. Curve 3: apparent blood sugar of case 3 fed $50 \mathrm{~g}$. glucose $(0.8 \mathrm{~g}$. per $\mathrm{kg}$.). Curve 4 : apparent blood sugar of case 4 fed $16 \mathrm{~g}$. glucose $(1.4 \mathrm{~g}$. per kg.). The blood sugar did not drop significantly below the fasting level during the 5 hours following ingestion of glucose.
For amino acid investigation venous blood was collected and the serum passed through a column of Zeo Karb 225 (a sulphonated polystyrene resin). Proteins, sugar, acids and all other non-basic components were washed away with water, and the amino acids desorbed with $5 \mathrm{M}$-ammonia solution. The ammonia eluate was evaporated in vacuo and the residue examined by two-dimensional paper chromatography without further treatment. Urinary amino acids were examined by two-dimensional paper chromatography (13) after electrolytic desalting.

\section{RESULTS AND INTERPRETATION}

\section{Glucose tolerance}

The glucose tolerance curves for the four subjects are shown in Figure 1. The values for cases 1 and 2 represent "true blood sugar" (see below) and were determined by the method given above, those for cases 3 and 4 represent "apparent blood sugar" determined by a modification of the method of Folin and $\mathrm{Wu}(15,16)$. All four show a normal rise and fall, the blood sugar returning to the fasting level within $2 \frac{1}{2}$ hours with no evidence of an abnormal fall within 5 hours.

\section{Effect of hormones}

Glucose insulin tolerance test (17). Case 2: Glucose (10 g.) was given by mouth and, simultaneously, 1.0 unit of insulin intravenously. The fasting blood sugar was $28.5 \mathrm{mg}$. per $100 \mathrm{ml}$. and rose to $91 \mathrm{mg}$. per $100 \mathrm{ml}$. at 30 minutes falling to $38 \mathrm{mg}$. per $100 \mathrm{ml}$. at 90 minutes.

Case 4: Glucose (19 g.) was given by mouth and 1.1 units of insulin intravenously. The fasting blood sugar was $31 \mathrm{mg}$. per $100 \mathrm{ml}$. and rose to $121 \mathrm{mg}$. per $100 \mathrm{ml}$., at 30 minutes, falling to 34 mg. at 60 minutes.

Adrenaline tolerance test. Adrenaline (0.2 mg.) was given subcutaneously after an 8-hour fast to cases 1,2 , and 4 . The blood sugar level rose in the first half-hour from 27 to $45 \mathrm{mg}$. per $100 \mathrm{ml}$. in case 1 , from 45 to 140 in case 2 and from 52 to 115 in case 4 . The blood sugar was still high after 2 hours (50, 93, and $87 \mathrm{mg}$. per $100 \mathrm{ml}$., respectively).

Glucagon. After an 8-hour fast glucagon ${ }^{2}$ was given intramuscularly to cases 1 and 4 (7,500 and 10,000 cat units, respectively). In case 1 the blood sugar level rose from 30 to a peak of $94 \mathrm{mg}$.

2 This was supplied by Eli Lilly \& Co., to whom our thanks are due. 
per $100 \mathrm{ml}$. in 15 minutes, followed by a steady fall to $38 \mathrm{mg}$. per $100 \mathrm{ml}$. at 90 minutes. In case 4 the blood sugar rose from 31 to $92 \mathrm{mg}$. per 100 $\mathrm{ml}$. in 30 minutes and fell to $35 \mathrm{mg}$. per $100 \mathrm{ml}$. by 2 hours. Case 1 was given $14 \mathrm{gm}$. of casein over 30 minutes and immediately after this had been ingested 7,500 cat units of glucagon were given by intramuscular injection. The fasting blood sugar was $32 \mathrm{mg}$. per $100 \mathrm{ml}$. and after the casein had been given it fell to $19 \mathrm{mg}$. per $100 \mathrm{ml}$. Half-an-hour after the injection of glucagon the blood sugar level had risen to $76.5 \mathrm{mg}$. per $100 \mathrm{ml}$. and 2 hours later still it was $90.5 \mathrm{mg}$. per $100 \mathrm{ml}$.

A.C.T.H. and cortisone. A.C.T.H. gel (10 mg.) was given intramuscularly twice daily for 10 days to case 1 . The blood sugar level was higher in the mornings but fell to its previous level later in the day. Although there were no convulsions during this period A.C.T.H. did not cause any striking alteration of blood sugar levels throughout the day. Three weeks later $10 \mathrm{mg}$. of cortisone was given 5 times daily for 3 days. No effect on the blood sugar levels was noted.

A.C.T.H. (10 mg.) was given by intramuscular injection 6 hourly to case 2 for 6 days and later $100 \mathrm{mg}$. cortisone was given daily by mouth in divided doses for 11 days. In both instances there was a slight rise in blood sugar levels throughout the day and the patient had no fits.

Cortisone $(20 \mathrm{mg}$.) was given twice daily for 18 days to case 4 and then the dose was increased to $60 \mathrm{mg}$. daily. After this the fasting blood sugar rose to 40 to $61 \mathrm{mg}$. per $100 \mathrm{ml}$. and the levels of blood sugar before feeds varied between 75 and $107 \mathrm{mg}$. per $100 \mathrm{ml}$. Before cortisone was given the fasting blood sugar varied from 17 to $50 \mathrm{mg}$. per $100 \mathrm{ml}$. and the blood sugar levels ranged from 35 to $45 \mathrm{mg}$. per $100 \mathrm{ml}$. throughout the day. The cortisone was given for 8 months and during this time he had no fits.

In cases 1,2 , and 4 there was no evidence of hyper-sensitivity to insulin and the hyperglycemic response to adrenaline and glucagon was normal. Casein did not prevent the hyperglycemic effect of glucagon in case 1 .

A.C.T.H. and cortisone were given in too small doses and for too short a period to case 1 for any conclusions to be drawn. In case 2 although there was no striking alteration in blood sugar levels clinical improvement was evident. Cortisone ef-

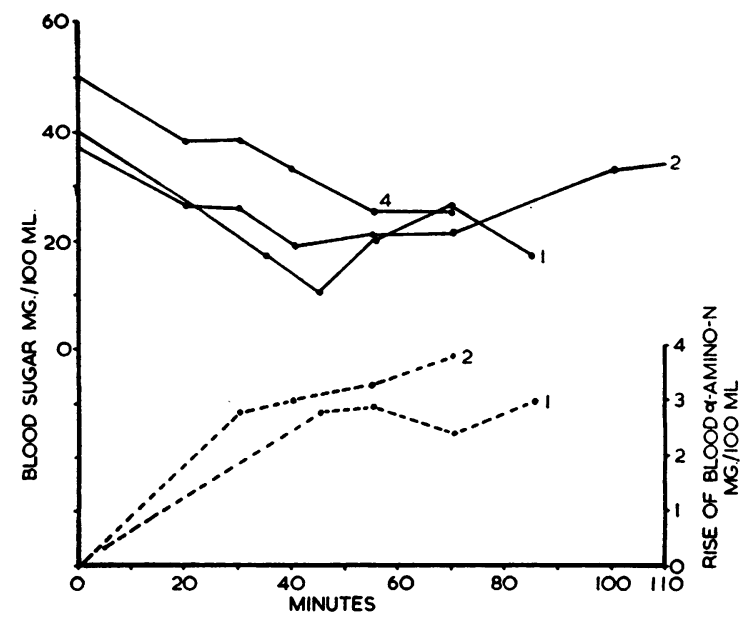

Fig. 2. Blood Sugar (-) and Amino-Nitrogen Rise (-- ) of Cases 1, 2 and 4 after Being Fed Casern

Case 1 fed $14 \mathrm{~g}$. casein (1.5 g. per kg. body weight) over 25 mins. Case 2 fed $16 \mathrm{~g}$. casein ( $1.5 \mathrm{~g}$. per kg.) over 10 mins. Case 4 fed $24 \mathrm{~g}$. casein ( $1.5 \mathrm{~g}$. per kg.) over 10 mins.

fected an improvement both in the clinical state and in the levels of blood sugar in case 4.

\section{Effect of protein}

The effects of feeding casein to three fasting patients are shown in Figure 2. The upper curves show the blood sugar concentrations, the lower

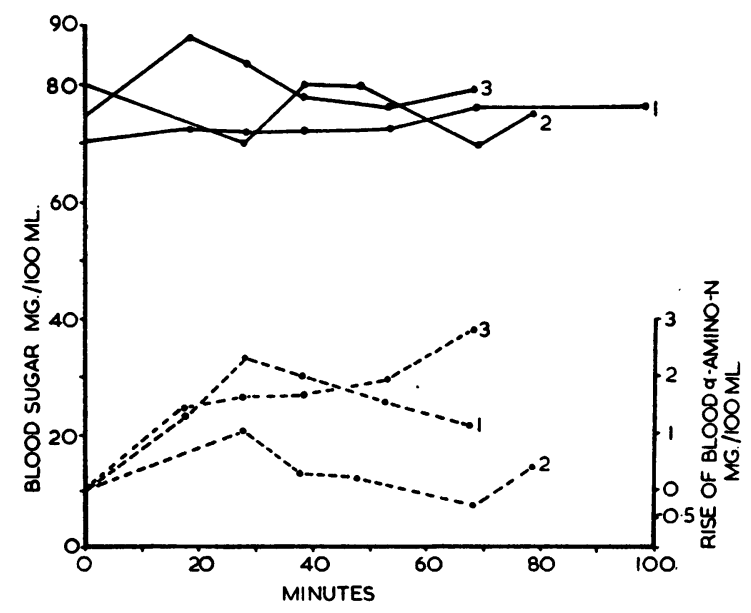

Fig. 3. Blood Sugar (-) and Amino-Nitrogen Rise (--) of Three Normal Subjects after Being Fed Casein

1 -was fed $16 \mathrm{~g}$. (1.5 g. per kg. body weight) over 8 mins., 2-was fed $14 \mathrm{~g}$. ( $1.5 \mathrm{~g}$. per kg.) over 8 mins., 3 was fed $26 \mathrm{~g}$. ( $1.5 \mathrm{~g}$. per $\mathrm{kg}$.) over 18 mins. 


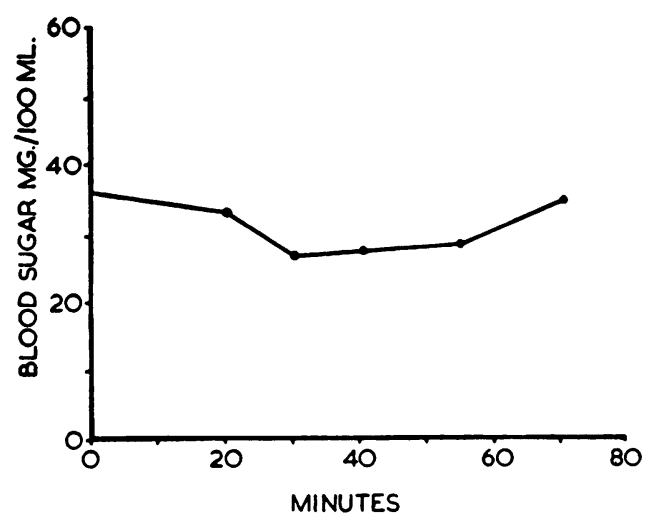

Fig. 4. Blood Sugar of a Fifth Case of Hypoglycemia after Being Fed 17.6 g. of Casein (1.5 g. Per Kg. BODY WEIGHT) OVER 10 MiNs.

This child's condition had been diagnosed as spontaneous idiopathic hypoglycemia.

curves the changes in the corresponding blood amino acid concentrations. Figure 3 shows the blood sugar concentrations and the changes in blood amino acid concentration when casein was fed to fasting normal subjects. The method of measuring blood amino acid levels is adequate for changes in level after feeding protein, but cannot measure absolute amino acid concentrations with any accuracy (12).

The casein had a marked hypoglycemic effect on the three patients, but none on the normal sub-

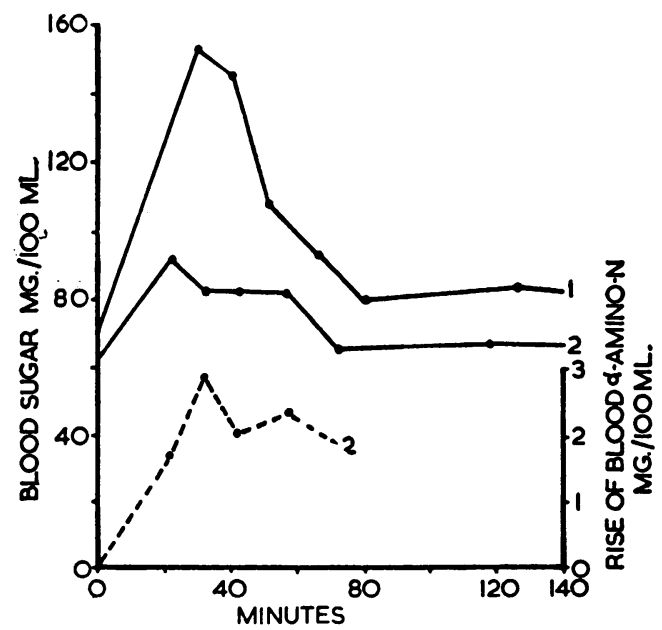

Fig. 5. 1: Blood Sugar of a Normal Subject after Being Fed 12 g. Glucose Alone (1.65 g. Per Kg. Body Weight) OVER 20 Mins. 2: (-) Blood Sugar and (--) Blood Amino-Nitrogen Rise of the Same Subject after Being Fed $12 \mathrm{~g}$. Glucose ANd $11 \mathrm{~g}$. Casein over 12 Mins. jects, yet the rise in blood amino acids was similar in both groups. The blood amino acid peak coincided in time with the minimum of the blood sugar concentration.

The effect on the blood sugar of feeding a normal subject a test dose of glucose alone and, next day, an equal dose of glucose with casein added is shown in Figure 5, together with the change of blood amino acid level. In case 1 a test dose of $13 \mathrm{~g}$. casein and $14 \mathrm{~g}$. glucose caused a slight initial rise in the blood sugar level from 47 to 58 mg. per $100 \mathrm{ml}$. after 10 minutes, followed by a profound fall to $26 \mathrm{mg}$. per $100 \mathrm{ml}$. at 20 minutes and $18 \mathrm{mg}$. per $100 \mathrm{ml}$. at 45 minutes. The blood sugar rose to $31 \mathrm{mg}$. per $100 \mathrm{ml}$. after 60 minutes. The results of the casein-glucose tests were, however, more variable than the other tests.

Gelatine had only a slight hypoglycemic effect on case 1, and tyrosine none at all (Figure 6). The rise in blood amino acids was as rapid after feeding gelatine as after casein.

\section{Effect of leucine}

Leucine caused a profound fall in blood sugar in the four patients, but had no comparable effect in normal subjects (Figure 7). Generally the blood sugar concentration in the patients dropped to about half the fasting value 30 to 45 minutes after all the test dose had been ingested, and

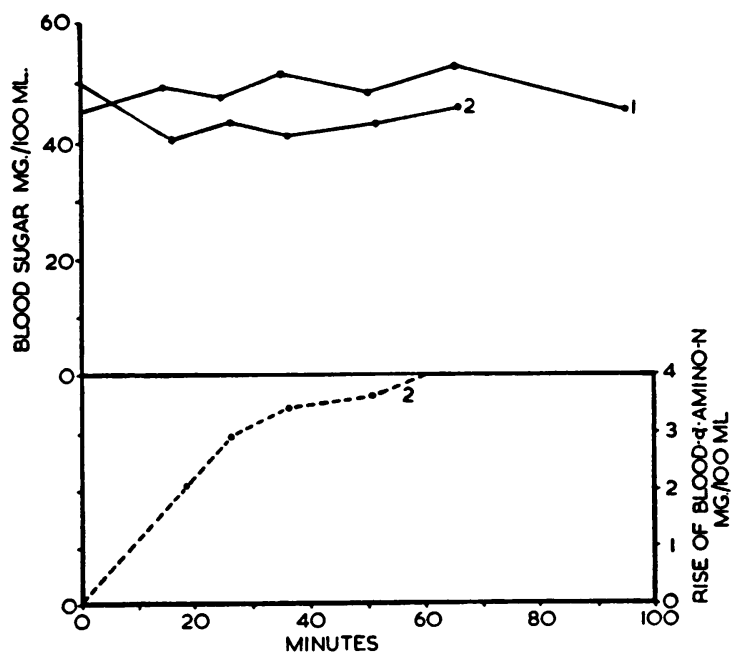

Fig. 6. 1: Blood Sugar of Case 2 after Being Fed 1 g. Tyrosine over 5 Mins. 2: Blood Sugar (-) and Blood Amino-Nitrogen Rise (-- ) of Case 2 after Being Fed 16 g. of Gelatine ( 1.5 g. Per KG.) over 6 Mins. 


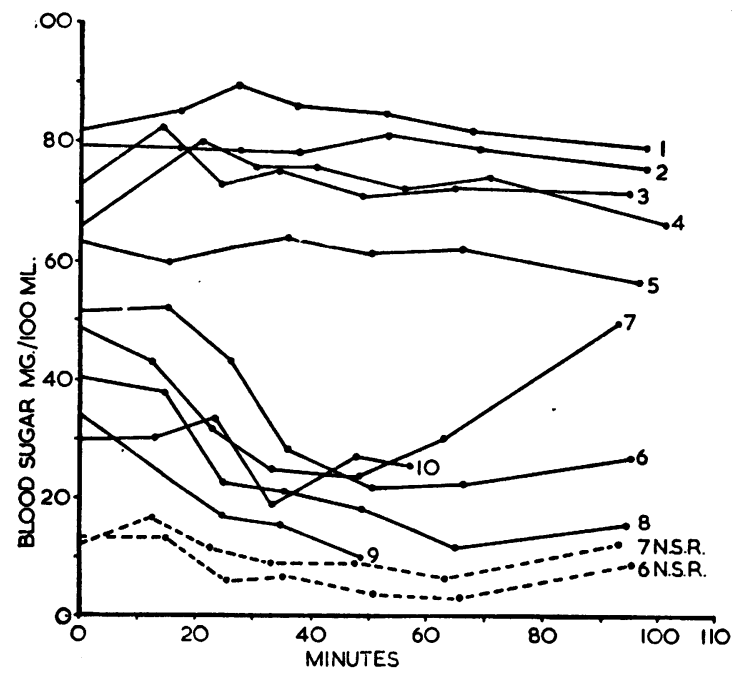

Fig. 7. Blood Sugar (-) of the Four Cases of Hypoglycemia (Curves 6, 7, 8, 9, 10) and of Frve Normal Individuals (Curves 1, 2, 3, 4, 5) after Being Fed L-LEUCINE

1: Fed $10 \mathrm{~g}$. leucine (.15 g. per $\mathrm{kg}$. body weight) over 7 mins.

2: Fed $12.7 \mathrm{~g}$. leucine (.15 g. per kg.) over 7 mins.

3: Fed $1.4 \mathrm{~g}$. leucine (.125 g. per kg.) over 6 mins.

4: Fed $2.1 \mathrm{~g}$. leucine (.3 g .per kg.) over $10 \mathrm{mins}$.

5 : Fed $1.2 \mathrm{~g}$. leucine (.155 g. per kg.) over 5 mins.

6: Case 2 fed $1.6 \mathrm{~g}$. leucine (.15 g. per kg.) over 5 mins.

7: Case 3 fed $5.2 \mathrm{~g}$. leucine (.083 g. per kg.) over 2 mins.

8: Case 2 fed $2.4 \mathrm{~g}$. leucine ( $.225 \mathrm{~g}$. per kg.) over 4 mins.

9: Case 1 fed $1.4 \mathrm{~g}$. leucine (.15 g. per kg.) over 4 mins.

10: Case 4 fed $2.3 \mathrm{~g}$. leucine ( $.15 \mathrm{~g}$. per kg.) over 5 mins.

---: Non-sugar reducing substances of cases 2 and 3 determined simultaneously with the true blood sugars shown in curves 6 and 7.

reached the fasting level again after 60 to $90 \mathrm{~min}$ utes. Increasing the dose of leucine depressed the blood sugar level further and for a longer time (Figure 7, curves 6 and 8 ). The clinical effects of leucine varied: case 2 became drowsy and fell asleep 40 minutes after the test dose of $2.4 \mathrm{~g}$. (Figure 7, curve 8 ); case 3 developed marked pallor 30 minutes after the test dose but did not complain of feeling unwell; in cases 1 and 4 severe convulsions occurred 45 and 54 minutes, respectively, after feeding the leucine, so that the experiment was terminated and glucose administered. No clinically observable effects were noted in any of the normal subjects. The dose of leucine fed was generally $0.15 \mathrm{~g}$. per $\mathrm{kg}$. body weight, i.e., equal to the leucine contained in the standard test dose of casein; however, one of the normal subjects was fed twice this dose (Figure 7, curve 4 ), case 2 was fed one and one-half times this dose on one occasion (Figure 7 , curve 8 ), and case 3 was fed only $0.083 \mathrm{~g}$. per $\mathrm{kg}$. (Figure 7, curve 7$)$. He was fed the same dose as the other patients if one takes body weight to the power two-thirds as the basis of calculation (18) but on this basis the two adult normal subjects were fed about twice the standard dose of leucine.

\section{Effect of isovaleric acid}

Figure 8 shows the effect on the blood sugar of feeding commercial isovaleric acid to case 2 and to a normal subject. Commercial isovaleric acid contains only 55 to 60 per cent true isovaleric acid ( $\beta$-methyl- $n$-butyric acid) the remainder being methylethylacetic acid (19, cf. 20). Hence case 2 (Figure 8, curve 2) was fed a dose of isovaleric acid corresponding to $0.085 \mathrm{~g}$. of L-leucine per $\mathrm{kg}$. body weight, while the normal subject (Figure 8, curve 2) was fed the equivalent of 0.15 g. L-leucine per $\mathrm{kg}$.

True blood sugar and non-sugar reducing substances

The method briefly described here removes all known non-sugar reducing substances, but does not differentiate one sugar from another; it is a "true sugar" method but not a "true glucose" method ( $c f .14)$. It will be described in greater

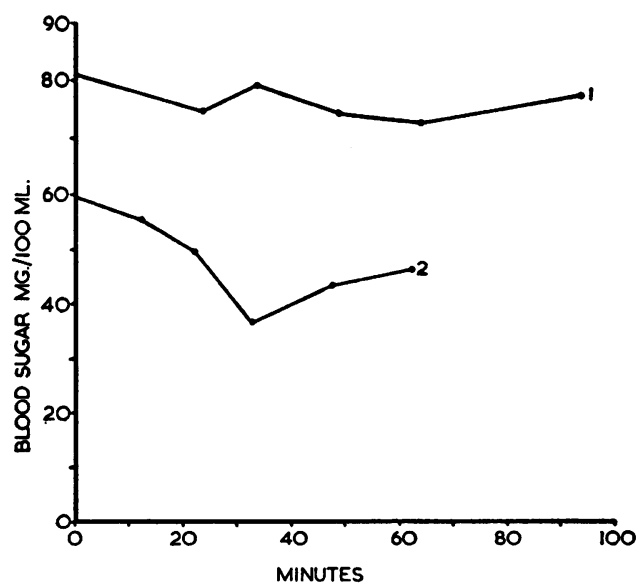

Fig. 8. Blood Sugar after Being Fed Isovaleric Acid

1: A normal subject fed $2.7 \mathrm{~g}$. commercial isovaleric acid (.21 g. per $\mathrm{kg}$. body weight) over 3 mins. 2: Case 2 fed $1.36 \mathrm{~g}$. commercial isovaleric acid (.12 g. per $\mathrm{kg}$.) over 2 mins. 
detail elsewhere (21). With the exception of the glucose tolerance curves for cases 3 and 4 (Figure 1, curves 3 and 4), all the blood sugar values shown in Figures 1 to 8 were determined by this method.

In every specimen, in addition to the "true sugar," the "apparent sugar" was determined by omitting the treatment with Biodeminrolit $G$, the difference giving a value for non-sugar reducing substances (N.S.R.) remaining after tungstic acid precipitation. In the normal subjects the concentration of N.S.R. was equivalent to $13.4 \pm$ 3.3 (S.D.) mg. of glucose per $100 \mathrm{ml}$. of blood (28 samples). The values were constant, within experimental error, for any given individual over the 90 minutes of a blood sugar curve, and were unaffected by feeding casein, glucose, leucine or isovaleric acid, but they varied slightly from day to day, and more markedly from individual to individual.

Most of the fasting specimens of blood from cases $1,2,3$, and 4 had values for N.S.R. that fell within the normal range. However feeding leucine caused a marked fall in N.S.R. in cases 1,2 , and 3 (from 13.5 to $5.5 \mathrm{mg}$. "glucose" per $100 \mathrm{ml}$. blood for case 1 ; from 15.5 to 3.5 and from 14 to 3 for case 2 ; from 16.5 to 6.5 for case 3 ), the minimum value occurring 10 or 15 minutes later than the minimum for the true glucose (Figure 7 ) and the value returning to near normal in 90 minutes. In case 4 the fasting N.S.R. was equivalent to only $5 \mathrm{mg}$. glucose per $100 \mathrm{ml}$. blood and did not show any further fall on feeding leucine. Casein caused a similar but less marked drop in N.S.R. in cases 1,2 , and 4 ; case 3 was not fed casein. Gelatine, tyrosine and isovaleric acid had no effect on the N.S.R. in case 2. Feeding glucose had no effect at all on the N.S.R. in any of these cases nor did the injection of glucagon.

In another hypoglycemic child (not reported in detail, see Figure 4) the fasting N.S.R. was equivalent to only $2.5 \mathrm{mg}$. glucose per $100 \mathrm{ml}$. blood. On feeding casein the value dropped steadily to $1 \mathrm{mg}$. per $100 \mathrm{ml}$. at 30 and 45 minutes then rose to $2.5 \mathrm{mg}$. per $100 \mathrm{ml}$. at 60 minutes.

In case 1 most of the values for N.S.R. fell in the normal range, but when she was being fed breast milk, and was clinically rather better, a single preprandial specimen of blood at 2 p.m. had a "true sugar" content of $19 \mathrm{mg}$., and N.S.R. equivalent to $70 \mathrm{mg}$. glucose per $100 \mathrm{ml}$. Four hours later these values were: true sugar $=36$, N.S.R. $\equiv 46 \mathrm{mg}$. glucose per $100 \mathrm{ml}$. blood. Next day, at 6 a.m. her fasting true sugar was 56 , and N.S.R. $\equiv 16 \mathrm{mg}$. glucose per $100 \mathrm{ml}$. blood; the value for N.S.R. remained between 16 and 18 for the rest of the day.

On another day, when case 1 was being fed "Soylac," her blood glucose values were as follows :

\begin{tabular}{lcccc}
\multicolumn{5}{c}{ Mg. glucose per $100 \mathrm{ml}$. blood } \\
Time & 6 a.m. & 10 a.m. & 11.40 a.m. & 2 p.m. \\
True sugar & 20 & 13 & 16 & 19 \\
N.S.R. & 28 & 13 & 6 & 2
\end{tabular}

By paper chromatography. While case 1 was on a cow's milk high protein diet, and suffering very frequent fits, her apparent blood sugar, determined by a modification of the method of Folin and $\mathrm{Wu}$ $(15,16)$, was $37 \mathrm{mg}$. per $100 \mathrm{ml}$., but by paper chromatography the glucose content was found to be $8.5 \pm 1 \mathrm{mg}$. per $100 \mathrm{ml}$. Earlier the same day her blood glucose was $20 \mathrm{mg}$. per $100 \mathrm{ml}$. by paper chromatography, but her apparent blood sugar was $60 \mathrm{mg}$. per $100 \mathrm{ml}$. by the method of Folin and $\mathrm{Wu}$. No sugar other than glucose was detected in either specimen.

There was never any detectable loss of glucose in the urine, either spontaneously or after feeding casein, in any of the patients. The other urinary sugars were normal. After case 4 had been fed glucose for a tolerance test, his urinary glucose reached $5 \mathrm{mg}$. per $100 \mathrm{ml}$., but this is still within normal limits.

The fasting blood concentrations of the different amino acids were normal in cases 1,2 , and 3 but somewhat higher than average in case 4 (two specimens), the relative proportions of the different amino acids were normal in all four. No explanation could be found, among the amino

TABLE I

Serum leucine content before and after a test dose of leucine

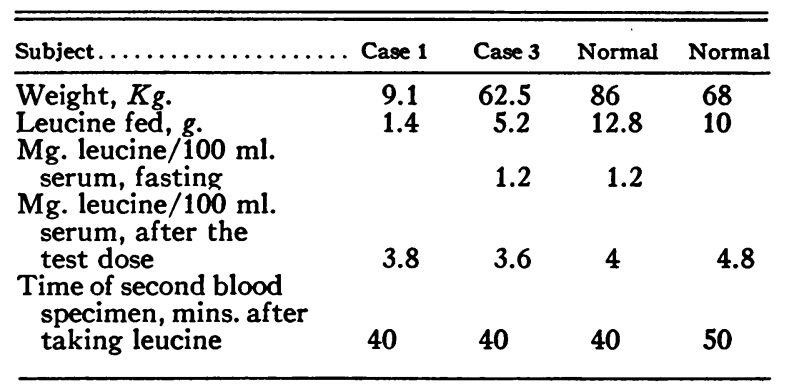


acids, for the abnormally high blood content of non-sugar reducing substances in case 1 . After feeding leucine similar rises of the blood leucine content took place in two normal subjects, case 1 and case 4 (Table I), with no detectable change in the other amino acids.

In case 4 there was some degree of general amino aciduria, but in cases 1 and 2 the urinary amino acids were normal; they were not examined in case 3.

\section{DISCUSSION}

McQuarrie, Ulstrom, and Ziegler have referred to a special group with "infantile idiopathic hypoglycemosis" (22) in whom the age of onset of symptoms and the physical and laboratory findings are very similar to our present cases 1,2 , and 3 .

In 1936, Conn (23) suggested the use of a high protein, low carbohydrate diet in the cases of idiopathic functional hypoglycemia. Subsequently this diet regimen has been tried in many cases of unexplained hypoglycemia. Talbot, Crawford, and Bailey's (24) case, prior to receiving alloxan, was tried on high protein, low carbohydrate feeds and it was noted that "during this period, the fasting blood sugar concentrations fell and the patient became so much worse that it became necessary to institute intravenous dextrose therapy." McQuarrie (6) also says of one of his patients on a similar diet that "her clinical state appeared to be getting worse with more frequent spells of irritability, staring and loss of consciousness."

The clinical observation that our patients (cases 1 and 2) had more fits when on a high protein diet led to an investigation of their blood sugar after feeding a test dose of casein. The result established a clear causative relation between the protein feeding and the hypoglycemia. To see whether this was a general effect of protein or amino acids, or whether some particular amino acid was responsible, one child was fed a test dose of gelatine, a protein with a very different amino acid composition from that of casein. Since there was a much smaller fall in the blood sugar concentration following gelatine it was probable that some particular amino acid or combination of amino acids was responsible for the hypoglycemia and a systematic search was started.

Tyrosine, which is almost absent from gelatine but composes 6.4 per cent of casein, was investi-
TABLE II

COMPOSITION OF MATERIALS FED TO CASES I AND 20

\begin{tabular}{|c|c|c|c|c|c|}
\hline & CASEIN $\%$ & CELATIN \% & $\begin{array}{c}\text { HUMAN } \\
\text { MILK. } \\
\text { G. } \\
\text { PER }\end{array}$ & $\begin{array}{l}\text { COWs' } \\
\text { MILK. } \\
\text { G. } \\
\text { PER IOOM }\end{array}$ & $A C \%$ \\
\hline PROTEIN & - & - & 1.25 & $3 \cdot 5$ & 26 \\
\hline CARBOHYDRATE & - & $\cdot$ & $7 \cdot 5$ & $4 \cdot 8$ & 53 \\
\hline LEUCINE & 10.0 & $3 \cdot 5$ & 0.12 & 0.38 & $2 \cdot 1$ \\
\hline TYROSINE & 6.4 & 0.5 & 0.06 & 0.21 & 1.0 \\
\hline PHENYLALANINE & 6.3 & $2 \cdot 3$ & 0.07 & 0.19 & $1 \cdot 4$ \\
\hline GLYCINE & $2 \cdot 1$ & 23.6 & 0.00 & 0.08 & 0.9 \\
\hline GUUTAMIC ACID & $23 \cdot 0$ & 11.0 & 0.21 & 0.75 & $4 \cdot 8$ \\
\hline ASPARTIC ACID & $7 \cdot 0$ & 6.2 & 0.10 & 0.25 & 1.0 \\
\hline ALANINE & $3 \cdot 3$ & $8 \cdot 2$ & 0.03 & 0.11 & 0.86 \\
\hline ISOLEUCINE & $7 \cdot 5$ & $1 \cdot 7$ & 0.08 & 0.26 & 1.6 \\
\hline VALINE & $7 \cdot 7$ & $2 \cdot 8$ & 0.11 & 0.24 & $1 \cdot 4$ \\
\hline TAYPTOPHAN & $1 \cdot 3$ & 0.0 & 0.02 & 0.05 & 0.36 \\
\hline
\end{tabular}

1 Compiled largely from Block and Bolling (49).

2 A preparation of Soya flour with added carbohydrate. We are indebted to Soya Foods Ltd., Elstree, England, for some of the data.

gated first, but proved to have no effect on the blood sugar concentration. L-leucine was tried next and had a most dramatic effect. The extent of the hypoglycemic response varied with the dose of leucine; the effects of test doses of casein and gelatine could be fully accounted for by their leucine content. Other amino acids are being investigated but the results obtained with leucine seemed to merit publication at this time.

A sufficient number of normal individuals were tested with casein and leucine to indicate that these substances did not produce a fall in blood sugar under fasting conditions.

Very little work has been published in which human blood sugar concentrations have been measured at intervals after administering single amino acids. Manzini and Arullani (25) have reported that 50 to $80 \mathrm{mg}$. of leucine injected subcutaneously into normal fasting men causes a fall of about 25 per cent in blood sugar concentration; this may be contrasted with the results of our feeding experiments. Schenck (26) found that glycine in 40 to $50 \mathrm{~g}$. oral doses caused a moderate reduction in the blood sugar concentrations of normal and diabetic adults (from 102 to 72 and from 256 to $161 \mathrm{mg}$. per $100 \mathrm{ml}$., respectively). Carballeira, Elrick, Mackenzie, and Browne (27) infused a mixture of ten amino acids (including 
L-leucine) intravenously into four normal fasting men and observed a slight drop (from 70 to 60 and from 76 to $60 \mathrm{mg}$. per $100 \mathrm{ml}$., respectively) in the blood sugar concentration in two of them 32 minutes after the mid-point of the infusion. A slight rise occurred in a third case and there was no change in the blood sugar of a fourth case.

There is considerable evidence in the literature suggesting an inter-relationship between the blood levels of amino acids, glucose, insulin, and adrenaline. Feeding glucose to normal men causes a drop in blood amino acid levels, leucine being depressed more than the other amino acids $(28,29)$. Insulin (100 units upwards) also causes a drop in blood amino acids, leucine again being the most strongly affected (28, $30 c f .31)$, but if glucose is continuously infused to keep the blood sugar above $80 \mathrm{mg}$. per $100 \mathrm{ml}$. after administering the insulin, there is no drop in blood amino acids (30, cf. 32).

Several workers have examined the effects of single amino acids, especially glycine, on the blood sugar of rabbits and dogs. A single oral, subcutaneous, or intravenous dose of glycine causes a rise in blood sugar level according to most workers (33-36) ; Folke Nord (33) and others have produced considerable evidence that glycine and some other amino acids act by causing the release of adrenaline. Schenck, on the other hand, found that glycine depressed the blood sugar level (26, $37)$, while others could find no effect $(38,39)$. According to some workers $(40,41)$ feeding glycine produces an initial hyperglycemia caused by the release of adrenaline, followed by prolonged hypoglycemia, caused by release of insulin in response to the hyperglycemia, though the liver plays some obscure part in the hypoglycemia (41). It is doubtful whether this explanation can account for all the results obtained by other work- ers. Manzini and Arullani $(25,35)$ found that leucine raised the blood sugar concentration of the rabbit but depressed that of man. The differences found by different workers for other amino acids may be partly explained by the use of different species.

A more relevant finding is that protein hydrolysates administered to humans simultaneously with glucose either intravenously (42) or orally (43) markedly reduce the height of the hyperglycemic curve that would result from administering the glucose alone, though the protein hydrolysate does not produce hypoglycemia in the fasting individual (43). (Compare Figure 5.) This may be compared with the finding of Chikano (39) that leucine, injected into rabbits, markedly reduced the hyperglycemia produced by injecting adrenaline or glucose, though it does not affect the fasting blood sugar level when given alone. However, Pollak (36) found that isovaleric acid had little or no effect on the glycemic curve in rabbits when fed with glucose.

For the four affected individuals considered here, but not for normal persons, leucine is a most potent drug, active when taken in comparatively low dosage. This effect must be distinguished from the toxic actions of the diamidines which cause hypoglycemia after initial hyperglycemia by depletion of liver glycogen stores $(44,45)$. Since leucine is always present in the blood it may be partly responsible for the low fasting blood sugar levels of these patients. It remained to be decided whether leucine itself caused the hypoglycemic response or whether it was converted at an abnormally high rate to an active intermediate metabolite, possibly one not formed in normal individuals.

According to Coon (46) L-leucine is metabolized according to the following scheme:

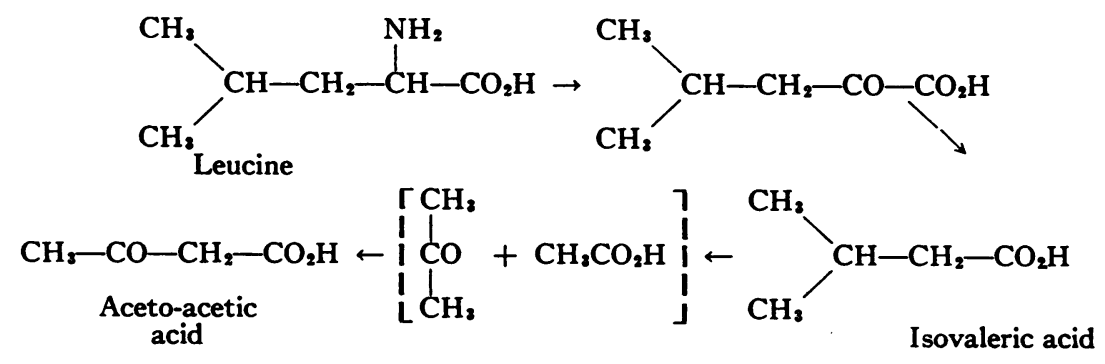


The keto-acid, formed from leucine by transamination, is not readily available. Isovaleric acid is split in vivo to a 3-carbon and a 2-carbon fragment, hypothetically acetone and acetic acid, each of which gives rise to aceto-acetic acid as endproduct. Aceto-acetic acid cannot be the active substance since it is formed from tyrosine which has no hypoglycemic effect. Hence isovaleric acid remains the one readily available metabolite of leucine that might have a hypoglycemic effect. A test dose of commercial isovaleric acid produced as profound a hypoglycemia in case 2 as did an equivalent dose of leucine (allowing for the purity of the commercial acid). In a normal subject, however, a larger dose of isovaleric acid had no effect on blood sugar concentration. The most likely explanation is that isovaleric acid is the true hypoglycemic factor in these four patients and that leucine acts by virtue of its rapid conversion to isovaleric acid; a less likely alternative is that leucine and isovaleric acid have a similar effect, by virtue of their somewhat similar molecular structure, on some aspect of the blood sugar regulating mechanism. In any case we have no definite explanation of why these patients react to leucine and isovaleric acid while normal individuals do not.

There was no evidence of any abnormality of the liver in these patients and the response to adrenaline and to glucagon were normal. Nor were there any clinical stigmata of abnormal function of the pituitary, thyroid or adrenal gland. In case 4 there was hyperplasia of the islet cells of the pancreas and, in two specimens of blood, a high insulin level, but in the other three cases there was no direct evidence of hyperinsulinism. McQuarrie, Ulstrom, and Ziegler (22) have, however, mentioned that "infantile idiopathic hypoglycemia suggests a form of hyperinsulinism but without evidence of hypertrophy, hyperplasia, or tumour of the $\beta$-cells."

The blood sugar curve produced by the administration of leucine or its metabolite is almost identical with that produced by giving insulin to a normal individual for an "insulin tolerance test" as described by Wilkins (47). In both tests the maximal drop in blood sugar concentration occurs at 30 to 45 minutes with a return to the fasting level in 60 to 90 minutes.

Tentatively we suggest that leucine or its me- tabolite, isovaleric acid, acts by one of two mechanisms : either (a) it may enhance the effect of circulating insulin on intracellular carbohydrate metabolism, or (b) it may cause an increased secretion of insulin by the islets of Langerhans. It should be possible, using present techniques, to differentiate the two possible modes of action, and work is proceeding on this. In normal humans or animals leucine (alone or in mixtures) causes a decrease in the hyperglycemic curve that follows administration of glucose; this can be explained as an enhancement of the effect of the insulin released in response to the hyperglycemia or, perhaps as the release of additional insulin. The second possibility is rendered less likely but not completely excluded by leucine having no hypoglycemic effect in fasting normal humans or animals; the blood insulin level is presumably so low under these conditions that any enhancing effect of leucine would be undetectable. Of the four patients who showed a hypoglycemic response to leucine while fasting, one has been shown to have an abnormally high blood insulin level, again supporting possibility (a) but not excluding (b). However, the failure of a fifth hypoglycemic child to show a marked hypoglycemic response to casein (Figure 4) suggests the possibility of two types of hypoglycemia.

We have no explanation of the changes observed in blood non-sugar reducing substances (N.S.R.). There can however be no doubt that these substances (generally considered to be mainly glutathione and erogthioneine) are closely bound up with the blood glucose. In diabetics the N.S.R. level is often abnormal $(21,48)$. In three of the cases of hypoglycemia reported here the fasting N.S.R. has been, on occasion, well outside the normal range. Finally the fall and rise of the N.S.R. curve when leucine or casein is fed parallels, but lags a little behind, the fall and rise of the blood glucose curve. The most surprising features are the extraordinarily rapid change in the N.S.R. when leucine or casein is fed and the failure of the fasting N.S.R. to rise when glucose or glucagon is administered.

Idiopathic hypoglycemia of the type seen in cases 1,2 , and 3 can be diagnosed by feeding a test dose of casein ( $1.5 \mathrm{~g}$. per $\mathrm{kg}$.) or L-leucine ( 0.15 g. per kg.) to the fasting subject and noting the blood sugar level at frequent intervals for the next 
ninety minutes. Other amino acids may well cause a fall in blood glucose and one of us (W.A.C.) is now investigating this possibility.

It would not be practical or even wise to attempt to restrict the protein intake of growing children but the results suggest that in this particular type of hypoglycemia high protein feeds should be avoided. We have suggested that small amounts of carbohydrate be given thirty to forty minutes after the ingestion of a feed to offset the effect of the protein in lowering the blood sugar. The natural course of the disease leads to less frequent fits as the child gets older but permanent mental deterioration will set in early in life if many hypoglycemic fits occur. The prognosis is good if acute hypoglycemic episodes are avoided by these means.

\section{SUMMARY}

Protein, leucine, or isovaleric acid, fed to three members of a family with spontaneous idiopathic hypoglycemia, caused a marked fall in the fasting true blood sugar level. They had a similar effect in a fourth child with hypoglycemia due to islet cell hyperplasia, but had no effect in normal fasting individuals. In another case of spontaneous idiopathic hypoglycemia casein had a less marked effect.

High protein feeds produced more fits and lower blood sugar values in the affected family than did a low protein diet.

The non-sugar reducing level was significantly outside the normal range in some blood samples from these patients and the apparent blood sugar level can be very misleading. The non-sugar reducing level fell nearly as fast as the true blood sugar level on feeding leucine or casein.

A casein test meal is advocated as a means of differentiating this type of hypoglycemia.

\section{ACKNOWLEDGMENTS}

We wish to thank Dr. W. Sheldon for permission to study and report on cases $1,2,3$, and 4 , and for his continued interest and help throughout the whole investigation. We should also like to thank Dr. B. Schlesinger for permission to study the fifth case of hypoglycemia. We are grateful to Dr. Martin Bodian for the histological reports on cases 2 and 4 , and Dr. P. J. Randle for estimating the plasma insulin-like activity. We acknowledge with thanks the assistance of Mrs. S. Zisman and Mrs. J. Campbell in the laboratory investigations and the co-operation of the nursing staff.
The Department of Medical Illustration drew Figures 1 to 8. One of us (L. I. W.) wishes to thank the Research Committee of The Hospital for Sick Children, Great Ormond Street, for a Research Fellowship during the tenure of which this investigation was carried out.

\section{REFERENCES}

1. Mann, F. C., and Magath, T. B., Studies on the physiology of the liver. II. The effect of the removal of the liver on the blood sugar level. Arch. Int. Med., 1922, 30, 73.

2. Harris, S., Hyperinsulinism and dysinsulinism. J.A. M.A., 1924, 83, 729.

3. Skillern, P. G., and Rynearson, E. H., Medical aspects of hypoglycemia. J. Clin. Endocrinol. \& Metab., 1953, 13, 587.

4. Hartman, A. F., and Jaudon, J. C., Hypoglycemia. J. Pediat., 1937, 11, 1.

5. Conn, J. W., The diagnosis and management of spontaneous hypoglycemia. J.A.M.A., 1947, 134, 130.

6. McQuarrie, I., Idiopathic spontaneously occurring hypoglycemia in infants. Am. J. Dis. Child., 1954, 87, 399.

7. Randle, P. J., Private communication.

8. Randle, P. J., Assay of plasma insulin activity by the rat-diaphragm method. Brit. Med. J., 1954, I, 1237.

9. Groen, J., Kamminga, C. E., Willebrands, A. F., and Blickman, J. R., Evidence for the presence of insulin in blood serum. A method for an approximate determination of the insulin content of blood. J. Clin. Invest., 1952, 31, 97.

10. Somogyi, M., Notes on sugar determination. J. Biol. Chem., 1952, 195, 19.

11. Nelson, N., A photometric adaptation of the Somogyi method for the determination of glucose. J. Biol. Chem., 1944, 153, 375.

12. West, C. D., Wilson, J. L., and Eyles, R., Blood amino nitrogen levels. Changes in blood amino nitrogen levels following ingestion of proteins and of a protein hydrolysate in infants with normal and with deficient pancreatic function. Am. J. Dis. Child., 1946, 72, 251.

13. Woolf, L. I., Paper chromatography. Great Ormond Street J., 1951, no. 2, 61.

14. Woolf, L. I., Use of ion-exchange resins in paper chromatography of sugars. Nature, 1953, 171, 841.

15. Folin, O., and Wu, H., A system of blood analysis. Supplement I. A simplified and improved method for determination of sugar. J. Biol. Chem., 1920, 41, 367.

16. Payne, W. W., Unpublished observations.

17. Fraser, R. W., Albright, F., and Smith, P. H., The value of the glucose tolerance test, the insulin tolerance test, and the glucose-insulin tolerance test in the diagnosis of endocrinologic disorders of glucose metabolism. J. Clin. Endocrinol., 1941, 1, 297. 
18. Martindale, W., The Extra Pharmacopoeia. 22nd ed., London, The Pharmaceutical Press, 1941, vol. 1, p. xxxvi.

19. James, A. T., Private communication.

20. James, A. T., and Martin, A. J. P., Gas-liquid partition chromatography: The separation and microestimation of volatile fatty acids from formic acid to dodecanoic-acid Biochem. J., 1952, 50, 679.

21. Woolf, L. I., and Cochrane, W. A., In preparation.

22. McQuarrie, I., Ulstrom, R. A., and Ziegler, M. R., Random notes concerning the etiological mechanisms and treatment of spontaneous hypoglycemia. Acta paediat., 1954, 43, Suppl. 100, 481.

23. Conn, J. W., The advantage of a high protein diet in the treatment of spontaneous hypoglycemia. Preliminary report. J. Clin. Invest., 1936, 15, 673.

24. Talbot, N. B., Crawford, J. D., and Bailey, C. C., Use of mesoxalyl urea (alloxan) in treatment of an infant with convulsions due to idiopathic hypoglycemia. Pediatrics, 1948, I, 337.

25. Manzini, C., and Arullani, C., Azioni degli aminoacidi sui leucociti e sulla curva glicemica nell'uomo sano. Fisiol. e med., 1934, 5, 500.

26. Schenck, E. G., Uber die Beeinflussbarkeit der Blutzuckerregulation durch Eiweissstoffe, Aminosäuren und deren Derivate. II. Arch. f. exper. Path. u. Pharmakol., 1933, 170, 546.

27. Carballeira, A., Elrick, H., Mackenzie, K. R., and Browne, J. S. L., Effects of single intravenous injections of pituitary growth hormone to normal adult men. Proc. Soc. Exper. Biol. \& Med., 1952, $81,15$.

28. Harris, M. M., and Harris, R. S., Effect of insulin hypoglycemia and glucose on various amino acids in blood of mental patients. Proc. Soc. Exper. Biol. \& Med., 1947, 64, 471.

29. Munro, H. N., and Thomson, W. S. T., Influence of glucose on amino acid metabolism. Metabolism, 1953, 2, 354.

30. Mayer-Gross, W., and Walker, J. W., Circulating free amino-acids in hypoglycaemia. Brit. J. Exper. Path., 1949, 30, 530.

31. Flock, E. V., Block, M. A., Mann, F. C., Grindlay, J. H., and Bollman, J. L., The effect of glucose on the amino acids of plasma after total hepatectomy. J. Biol. Chem., 1952, 198, 427.

32. Drury, D. R., and Greeley, P. O., Intravenous injection of amino acids on glucose utilization rate of hypophysectomized and insulin-treated rabbits. Proc. Soc. Exper. Biol. \& Med., 1938, 39, 310.

33. Nord, F., Etude sur l'influence de quelques dérivés de l'albumine sur la régulation du sucre du sang. Acta. med. Scandinav., 1926, 65, 1.
34. Paasch, G., Uber die Wirkung des Glykokolls auf den Blutzucker. Biochem. Ztschr., 1928, 197, 460.

35. Manzini, C., and Arullani, C., Action des acides aminés sur les leucocytes et sur le courbe glycémique. Arch. ital. de biol., 1933, 89, 201.

36. Pollak, L., Uber den Einfluss von Aminosäuren und Fettsäuren auf die Blutzuckerregulation. Biochem. Ztschr., 1922, 127, 120.

37. Schenck, E. G., Utber die Beeinflussbarkeit der Blutzuckerregulation durch Eiweissstoffe, Aminosäuren und deren Derivative. I. Arch. f. exper. Path. u. Pharmakol., 1932, 167, 201.

38. Kanai, I., Uber den Einfluss von Aminosäuren auf den Blutzucker. Biochem. Ztschr., 1932, 248, 383.

39. Chikano, M., Uber den Einfluss von Aminosäuren und ihren Abkömmlingen auf die Adrenalinhyperglykämie. Biochem. Ztschr., 1929, 205, 154.

40. La Barre, J., Contributions l'étude des variations physiologiques de la sécrétion interne du pancréas. XIII. La fonction pancréatique endocrine au cours de l'hyperaminoacidémie expérimentale. Arch. internat. de physiol., 1934, 38, 37.

41. Kesztyüs, L., and Martin, J., Die Wirkung der Aminosäuren auf die Blutzuckerregulation bei EckFistelhunden. Arch. f. exper. Path. u. Pharmakol., 1936, $182,514$.

42. Lockhart, C. E., and Elman, R., The effect of intravenous glucose and amino acids on glycosuria and urinary output in humans. Surg. Gynec. \& Obst., 1949, 88, 97.

43. Grühn, F., Uber Beeinflussung des Kohlehydratstoffwechsels durch Aminosäuren. Artzl. Wchnschr., 1950, 5, 827.

44. Frank, E., Nothmann, M., and Wagner, A., Uber synthetisch dargestellte Körper mit insulinartiger Wirkung auf den normalen und diabetischen Organismus. Klin. Wchnschr., 1926, 5, 2100.

45. Hassall, C. H., and Reyle, K., Hypoglycin A and B, two biologically active polypeptides from Blighia sapida. Biochem. J., 1955, 60, 334.

46. Coon, M. J., The metabolic fate of the isopropyl group of leucine. J. Biol. Chem., 1950, 187, 71.

47. Wilkins, L., The Diagnosis and Treatment of Endocrine Disorders in Childhood and Adolescence. Springfield, Ill., Charles C Thomas, 1950.

48. Illing, E. K. B., Gray, C. H., and Lawrence, R. D., Blood glutathione and non-glucose reducing substances in diabetes. Biochem. J., 1951, 48, Proc. xxxiv.

49. Block, R. J., and Bolling, D., The Amino Acid Composition of Proteins and Foods; Analytical Methods and Results. 2nd ed., Springfield, Ill., Charles C Thomas, 1951. 